九州大学学術情報リポジトリ

Kyushu University Institutional Repository

\title{
Volatile Compounds of human Milk
}

Shimoda, Mitsuya

Laboratory of Food Process Engineering, Division of Food Biotechnology, Department of

Bioscience and Biotechnology, Faculty of Agriculture, Kyushu University

Yoshimura, Takashi

Laboratory of Food Process Engineering, Division of Food Biotechnology, Department of Bioscience and Biotechnology, Faculty of Agriculture, Kyushu University

Ishikawa, Hiroya

Laboratory of Food Analysis, Division of Bioresource and Bioenviromental Sciences, Graduate School, Kyushu University

Hayakawa, Isao

Laboratory of Food Process Engineering, Division of Food Biotechnology, Department of Bioscience and Biotechnology, Faculty of Agriculture, Kyushu University

他

https://doi.org/10.5109/24370

出版情報：九州大学大学院農学研究院紀要. 45（1)，pp.199-206，2000-11. Kyushu University バージョン：

権利関係: 


\title{
Volatile compounds of human milk
}

\author{
Mitsuya Shimoda, Takashi Yoshimura, Hiroya Ishikawa,* \\ Isao Hayakawa and Yutaka Osajima** \\ Laboratory of Food Process Engineering, Division of Food Biotechnology, Department of \\ Bioscience and Biotechnology, Faculty of Agriculture, \\ Kyushu University, Fukuoka 812-8581, Japan \\ (Received July 10, 2000 and accepted August 18, 2000)
}

\begin{abstract}
Volatile flavor compounds of human milk have been investigated comparing to commercial cow milk. Volatiles from the milks were isolated by simultaneous steam distillation-extraction (SDE) under reduced pressure using diethyl ether as a solvent. The odor concentrates were analyzed by gas chromatography and gas chromatography-mass spectrometry. Identified compounds from the human milk included 6 esters, 13 ketones, 6 fatty acids, 2 lactones, 24 aliphatic aldehydes, 9 alcohols, 18 hydrocarbons, and 6 miscellaneous compounds. The composition of volatile compounds was quite different from that of the cow milk. Of the volatiles in the human milk the primary important class was aldehydes, and the secondary one was volatile fatty acids.
\end{abstract}

\section{INTRODUCTION}

Human milk is an important medium for early sensory experiences of human infants. Human milk, however, is not a food of invariant flavor but like the milk of other animals human milk is also flavored by ingested compounds such as garlic, mint, vanilla, alcohol, etc.. It provides the potential for a rich source of varying chemosensory experiences to the infants, although human milk has to have a typical odor which is related to a human metabolism (Mennella, 1995).

Extensive work has been carried out on the effects of heat treatment and storage on the aroma of cow milk (Rerkrai et al., 1987; Badings, 1991; Gaafar, 1991; Contarini, et al., 1997). Detailed information on volatile flavor compounds in the raw milks from cow, ovine, caprine and water buffalo was provided by Moio et al. (1993a; 1993b; 1994). A large number of volatile flavor compounds from spray-dried skim milk powder were identified and quantified to make clear the flavor quality of skim milk (Shiratsuchi, et al., 1994a; 1994b; 1995).

To date, no information is available on the volatile flavor compounds of human milk. We have carried out a study on the identification and quantification of volatiles in human milk to investigate the early sensory experiences of human infants.

* Laboratory of Food Analysis, Division of Bioresource and Bioenvironmental Science, Graduate School, Kyushu University, Fukuoka 812-8581, Japan.

** School of Bioresources, Hirosima Prefectural University, 562 Nanatsuka-machi, Shoubaru, Hirosima, 727-0023, Japan 


\section{MATERIALS AND METHODS}

\section{Materials}

Fresh human milk ( $1 \mathrm{~L})$ was obtained from Meiji Milk Products Co., Ltd. (Tokyo) as a mixture of milks from Japanese voluntary mothers. The milk sample was frozen just after collection and stored in a glass bottle at $-20^{\circ} \mathrm{C}$ until it was analyzed (the storage time was about 2 weeks). Ultra-high temperature treated (UHT) cow milk (whole milk) as a reference was purchased from a market.

\section{Isolation of Volatile Flavor Compounds}

A milk sample $(1 \mathrm{~L})$ was placed in a $2000-\mathrm{mL}$ round bottom flask. Volatiles were separated with $80 \mathrm{~mL}$ of diethyl ether by simultaneous distillation-extraction under reduced pressure (approximately $100 \mathrm{mmHg}$ ) for $2 \mathrm{~h}$, using a modified Likens-Nickerson apparatus (SDE method). Temperature of the milk was about $62-65^{\circ} \mathrm{C}$ during the SDE operation. For the cow milk this SDE procedure was repeated 5 times. After addition of 2-ethylhexyl acetate $(20 \mathrm{ppb})$ as an internal standard, the extract solution was dried over anhydrous sodium sulfate for $15 \mathrm{~h}$ and concentrated to about $100 \mu \mathrm{L}$.

\section{Capillary Gas Chromatography (GC)}

Capillary GC analysis was carried out on a Hewlett-Packard Model 5890A gas chromatograph equipped with a flame ionization detector (FID) and connected to a Shimadzu Chromatopak C-R5A integrator. Separation was achieved on a $60 \mathrm{~m} \times 0.25 \mathrm{~mm}$ i.d. fused silica capillary column, coated with cross-linked polyethylene glycol $20 \mathrm{M}$, film thickness $0.25 \mu \mathrm{m}$ (DB-Wax; J\&W Scientific, Folsom, CA). The oven temperature was programmed from 50 to $230^{\circ} \mathrm{C}$ at $2^{\circ} \mathrm{C} / \mathrm{min}(40$-min hold). The injector and detector temperatures were 240 and $250^{\circ} \mathrm{C}$, respectively. The helium carrier gas flow rate was $28 \mathrm{~cm} / \mathrm{s}$ with an injection splitter at a split ratio of $20: 1$. Retention indices were estimated in accordance with a modified Kovats method (Van den Dool and Kratz, 1963).

\section{Capillary Gas Chromatography-Mass Spectrometry (GC-MS)}

Electron impact mass spectrometric data were collected on a JEOL Automass 50 mass spectrometer interfaced to a Hewlett-Packard 5890 Series II gas chromatograph. The column and chromatographic conditions were the same as described for GC analysis. The mass spectrometer was operated at an ionization voltage of $70 \mathrm{~V}$ and an ion source temperature of $200^{\circ} \mathrm{C}$. The mass spectra of unknown compounds were compared with those in the Wiley/NBS Registry of Mass Spectral Data (Wiley/NBS Registry of Mass Spectral Data, 1983).

\section{RESULTS AND DISCUSSION}

The recoveries of total volatiles were $1800 \mathrm{ppb}$ and $190 \mathrm{ppb}$ for the human and cow milk, respectively. The volatile concentrate from the human milk developed oily and aldehydic odors, on the contrary, the concentrate from the cow milk had sweet and milky odors. Total of 109 peaks from two milk samples were definitely or tentatively identified (Table 1). The area of the peaks identified represented 94 and $93 \%$ of the chromatogram 
Table 1. Comparison of volatile compounds in human and cow milk.

\begin{tabular}{|c|c|c|c|c|}
\hline \multirow{2}{*}{$\begin{array}{l}\text { Kovats } \\
\text { index }^{a}\end{array}$} & \multirow{2}{*}{ compounds } & & \multicolumn{2}{|c|}{ contents (ppb) } \\
\hline & & & in human milk & in cow milk \\
\hline \multicolumn{5}{|c|}{ Esters } \\
\hline 889 & ethyl acetate & & $-b$ & 20.1 \\
\hline 1638 & ethyl decanoate & & $\operatorname{tr}$ & - \\
\hline 1806 & methyl dodecanoate & & 4.1 & - \\
\hline 1839 & ethyl dodecanoate & & 2.4 & - \\
\hline 2005 & methyl tetradecanoate & & 1.3 & - \\
\hline \multirow[t]{3}{*}{2216} & methyl hexadecanoate & & 6.1 & - \\
\hline & & total & 13.9 & 20.1 \\
\hline & & Ketones & & \\
\hline 840 & acetone & & - & 1.8 \\
\hline 890 & 2 -butanone & & - & 9.0 \\
\hline 951 & 2,3 butanedione & & - & 1.0 \\
\hline 960 & 2-pentanone & & - & 2.1 \\
\hline 1047 & 2,3-pentanedione & & $\operatorname{tr}$ & $\operatorname{tr}$ \\
\hline 1177 & 2-heptanone & & 1.8 & 10.5 \\
\hline 1190 & cyclopentanone & & - & 0.1 \\
\hline 1239 & 6-methyl-2-heptanone ${ }^{d}$ & & $\operatorname{tr}$ & - \\
\hline 1255 & 3-octanone & & 5.6 & - \\
\hline 1308 & 4 octen-3-one & & 4.2 & - \\
\hline 1339 & 6-methyl-5-hepten-2-one ${ }^{d}$ & & 1.6 & - \\
\hline 1392 & 2-nonanone & & $\operatorname{tr}$ & 6.4 \\
\hline 1411 & 3-octen-2-one & & 2.8 & $\operatorname{tr}$ \\
\hline 1469 & $p$-menthan-3-one ${ }^{d}$ & & 1.0 & - \\
\hline 1503 & 2-decanone & & - & 0.1 \\
\hline 1517 & 3,5-octadien-2-one & & 1.0 & - \\
\hline 1598 & 2-undecanone & & 2.5 & - \\
\hline 1705 & 2-dodecanone & & - & $\operatorname{tr}$ \\
\hline 1816 & 2 tridecanone & & 1.6 & 2.2 \\
\hline 2028 & 2-pentadecanone & & - & 1.5 \\
\hline \multirow[t]{3}{*}{2211} & 2-heptadecanone & & - & $\operatorname{tr}$ \\
\hline & & total & 22.1 & 34.7 \\
\hline & & Acids & & \\
\hline 1452 & acetic acid & & $\operatorname{tr}$ & - \\
\hline 1625 & butanoic acid & & - & 0.4 \\
\hline 1852 & hexanoic acid & & - & 1.9 \\
\hline 1962 & heptanoic acid & & - & $\operatorname{tr}$ \\
\hline 2065 & octanoic acid & & 47.8 & 10.6 \\
\hline 2174 & nonanoic acid & & 3.1 & 0.7 \\
\hline 2277 & decanoic acid & & 445.3 & 37.0 \\
\hline 2389 & undecanoic acid & & 33.4 & 0.7 \\
\hline \multirow[t]{3}{*}{2493} & dodecanoic acid & & 868.8 & 20.6 \\
\hline & & total & 1398.4 & 71.9 \\
\hline & & Lactones & & \\
\hline 2053 & $\gamma$-nonalactone & & - & 0.7 \\
\hline 2112 & $\delta$-nonalactone & & - & 1.2 \\
\hline 2151 & $\gamma$-decalactone & & $\operatorname{tr}$ & - \\
\hline 2226 & $\delta$-decalactone & & - & 3.4 \\
\hline 2397 & $\gamma$-dodecalactone & & - & $\operatorname{tr}$ \\
\hline 2442 & $\delta$ dodecalactone & & 4.6 & - \\
\hline
\end{tabular}


Table 1. Continued. (1)

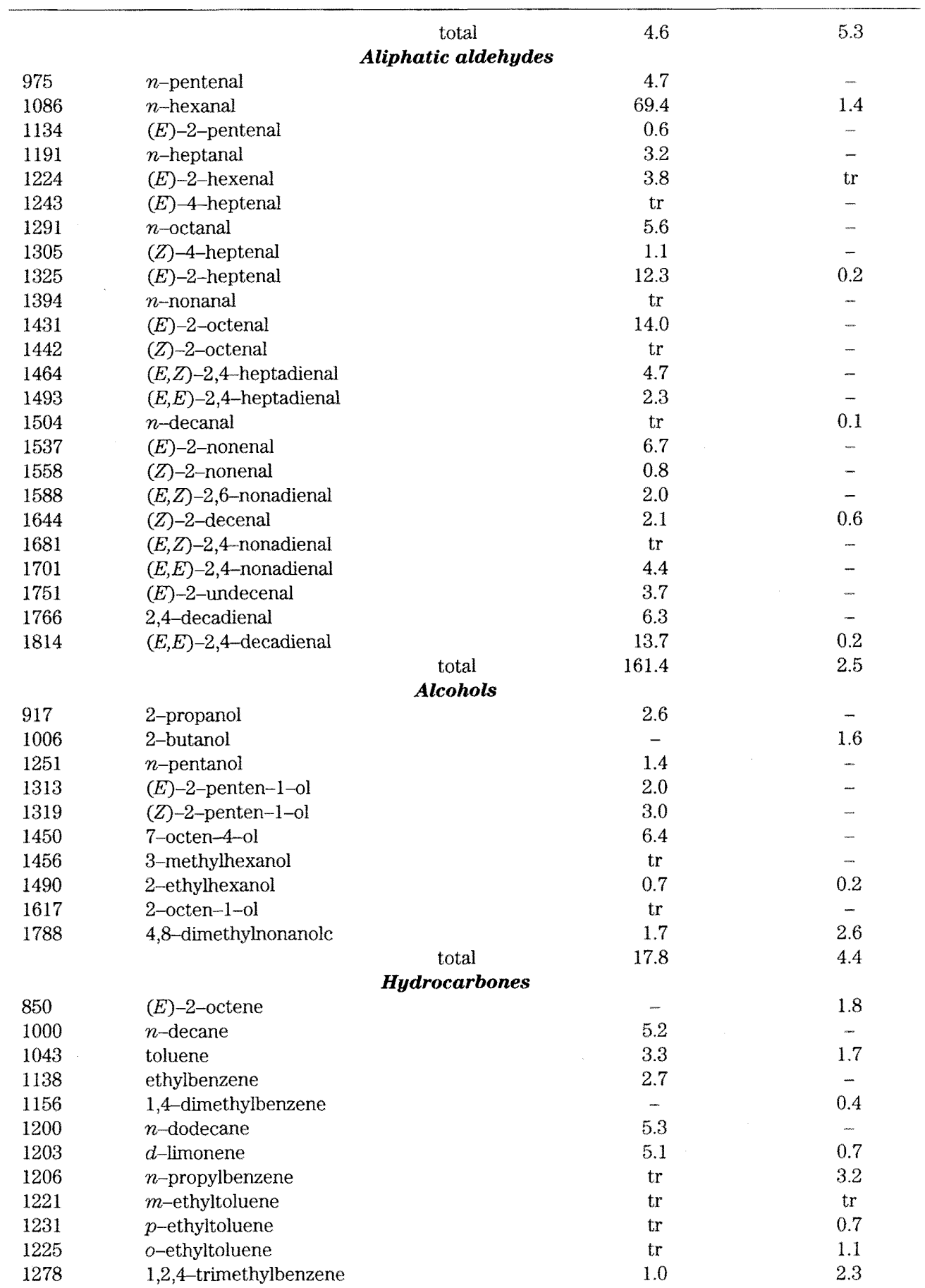


Table 1. Continued. (2)

\begin{tabular}{|c|c|c|c|}
\hline 1300 & $n$-tridecane & 2.2 & $\operatorname{tr}$ \\
\hline 1331 & 1,2,3-trimethylbenzene & 1.2 & 0.4 \\
\hline 1400 & $n$-tetradecane & 4.9 & - \\
\hline 1500 & $n$-pentadecane & 11.4 & 0.1 \\
\hline 1600 & $n$-hexadecane & - & 2.4 \\
\hline 1653 & caryophyllene & 1.9 & - \\
\hline 1700 & $n$-heptadecane & 1.8 & 0.8 \\
\hline 1800 & $n$-octadecane & 1.0 & 1.5 \\
\hline 1900 & $n$-nonadecane & - & 0.8 \\
\hline \multirow[t]{2}{*}{2000} & $n$-eicosane & 1.2 & 0.3 \\
\hline & \multicolumn{3}{|l|}{ Miscellaneous } \\
\hline 1512 & $1 H$-pyrrol & $\operatorname{tr}$ & $\operatorname{tr}$ \\
\hline 1522 & benzaldehyde & $\operatorname{tr}$ & 0.8 \\
\hline 1706 & $\alpha$-terpineol & $\operatorname{tr}$ & $\operatorname{tr}$ \\
\hline 1722 & $N$-butyl-N-nitrosobutanamine $e^{d}$ & - & $\operatorname{tr}$ \\
\hline 1734 & methylphenylamine & - & 0.3 \\
\hline 1764 & dimethylphenylmethanol & - & 1.4 \\
\hline 1770 & $N, N$-dibutylformamide & $\operatorname{tr}$ & $\operatorname{tr}$ \\
\hline 1813 & $N, N$-dibutylacetamide & $\operatorname{tr}$ & $\operatorname{tr}$ \\
\hline 1853 & geranylacetone & 2.4 & - \\
\hline 1988 & benzothiazole & - & 0.3 \\
\hline \multirow[t]{2}{*}{2093} & $p$-cresol & - & $\operatorname{tr}$ \\
\hline & total & 2.4 & 2.8 \\
\hline
\end{tabular}

${ }^{a}$ Modified Kovats indices calculated for DB-Wax capillary column.

${ }^{\circ}$ not detected.

${ }^{c}$ trace. ${ }^{d}$ Tentative identification by mass spectrum alone.

surfaces obtained from the human and cow milk, respectively (excluding solvent and internal standard). Figures in Table 1 were only approximate concentration since recoveries from the milk samples and FID response factors were not determined for each compound (assume all recoveries and response factors of 1.0). The compounds identified in the human milk included 6 esters, 13 ketones, 6 fatty acids, 2 lactones, 24 aliphatic aldehydes, 9 alcohols, 18 hydrocarbons, and 6 miscellaneous compounds.

Methyl and ethyl esters of fatty acids were identified. Methyl esters of dodecanoic, tetradecanoic and hexadecanoic acids and ethyl esters of decanoic and dodecanoic acid, however, were detected only from the human milk. Large amount of ethyl acetate was found in the cow milk. These are in disagreement with the fact that short-chain and medium-chain fatty acids are abundant in the milks from ruminant animals by the actions of rumen microorganisms (Christie, 1983). Furthermore, it was the most important characteristic that methyl esters were predominant in the human milk. According to Moio, et al. (1993a) aliphatic ethyl esters were the most important class of milk volatiles, comprising about half of the neutral volatile fraction of the milks from cow, ovine, caprine and water buffalo. Above all, ethyl esters of butyric, hexanoic, octanoic, and decanoic acids have been reported as the most representative compounds. They also found ethyl acetate only in cow and water buffalo milks. Ethyl esters of butyric, hexanoic and 
octanoic acids, however, were not found in the present milk samples (Table 1). Palmquist et al. (Palmquist, et al., 1993) demonstrated that the fat composition of cow milk was strongly influenced by the stage of lactation, dietary composition and feeding regimen.

Many chemical species of ketones, which are considered to be degradation products of hydroperoxides from unsaturated free fatty acids (Hawke, 1966; Dartey and Kinsella, 1971; Forss, 1979) were identified. Total concentration of ketones in the human milk was $22.1 \mathrm{ppb}$, on the other hand, $34.9 \mathrm{ppb}$ in the cow milk. There was great difference in the composition, that is, methyl ketones such as 2-butanone, 2-heptanone and 2-nonanone were predominant in the cow milk, and ethyl ketones such as 3-octanone and 4-octen-3-one were predominant in the human milk. Methyl ketones are the compounds which play a fundamental role in determining the typical odor of blue cheeses (Gallois and Langlois, 1990). The concentrations of these methyl ketones, however, in the cow milk were extremely low, far below the threshold value (500-8000 ppb) in fresh milk (Badings, 1984). Ethyl ketones have not been found in the milks from ruminant animals (Moio, et al., 1993a). These compounds were found in butter, chicken, beef, pork, etc. (Volatile Compounds in Food, 1992). These differences in the composition would be attributed to the differences in the composition of fatty acids and the activities of enzymes such as lipoxygenase, hydroperoxide lyase and hydroperoxide isomerase. Ethyl ketones in the human milk were unlikely to have sensory importance.

The chemical class with the highest proportion was free fatty acids, comprising 84 and $46 \%$ of the total volatile fraction of the human and cow milk, respectively. The amount of fatty acids from the human milk comprised to about 20 times as much as that from the cow milk. Since these compounds are known to be released from triglycerides and phospholipids by the action of milk lipase or bacterial lipase in ruminant animals, the activity of milk lipase in the human milk was considered to be higher than that in the cow milk. Octanoic, decanoic and dodecanoic acids were predominant compounds in both the milks. Considering the odor threshold values (200-800 ppb) (Osawa, 1987) these compounds would contribute to buttery, milky and creamy odors only in the human milk. Great difference in the amount of volatile acids in two milk samples would be attributed to the levels of volatile esters.

Among lactones, which are characterized by sweet, milky or creamy odors, $\delta$-deca and $\delta$-dodecalactone are associated with the smell of milk with sweet and body attributes (Osawa, 1987). Recently, it was also reported that $\delta$-deca and $\delta$-undecalactone, and $\gamma$ -undeca and $\gamma$-dodecalactone were the important contributors to the sweet and milky odors of spray-dried skim milk powder (Shiratsuchi, et al., 1995). $\gamma$-Nona, $\delta$-nona and $\delta$-decalactone were detected in the present cow milk, on the other hand, $\delta$-dodecalactone was predominant in the human milk. The sensory importance of lactones could not be clarified because the concentrations recovered were very low. The percent recoveries from cow milk were practically less than 5\% except for $\gamma$-nonalactone (8\%). It was considered that the binding of lactones to milk proteins lowered their volatilities. Studies (O'Neill and Kinsella, 1987a; 1987b) on the interaction of volatiles with proteins support this hypothesis.

Aldehydes in Table 1 except for 4-heptenal were oxidation products of oleic, linoleic and linolenic acid. $(E)$ - and $(Z)-4$-Heptenal are known to be the degradation product of $(Z, Z)-11,15$-octadecadienoic acid (Belitz and Grosch, 1987). The contributions of 
aldehydes to the odors of two milk samples were extremely different. These compounds in the concentrations found in human milk undoubtedly develop oily and aldehydic odors. Because their odor threshold values in aqueous phase are extremely low: hexanal; 4.5 (Byttery, et al., 1987), heptanal; $2.0 \mathrm{ppb}$ (Buttery, et al., 1994), octanal; $0.7 \mathrm{ppb}$ (Karahadian and Johnson, 1993), (Z)-4-heptenal; 0.06 ppb (Milo and Grosch, 1993), nonanal; $1.0 \mathrm{ppb}$ (Karahadian and Johnson, 1993), ((E)-2-octenal; $3.0 \mathrm{ppb}$ (Cha and Cadwallader, 1998), (E)-2-nonenal; 0.08 ppb (Karahadian and Johnson, 1993), (E,E)-2,4-nonadienal; $0.06 \mathrm{ppb}$ (Milo and Grosch, 1993), $(E, E)-2,4$-decadienal; $0.07 \mathrm{ppb}$ (Karahadian and Johnson, 1993).

Total concentration of alcohols in the human milk was about 4 times as much as that in the cow milk. Almost all of the compounds were degradation products of unsaturated fatty acids. Considering their quite high odor thresholds in milk (400-600 ppb) it was unlikely that they contributed to the milk odor.

As hydrocarbons 10 aliphatic compounds, 9 aromatic compounds, and 2 terpenes were found. Except for pentadecane in the human milk all compounds were present at low levels less than $10 \mathrm{ppb}$, so probably did not contribute to the milk odor.

Among miscellaneous compounds the possible contributors to milk odor were not found. Benzothiazole developed the off-flavor in spray dried skim milk powder (Shiratsuchi, et al., 1994b) but it was unlikely to have any sensory importance in the cow milk because of its low concentration.

In conclusion, the results showed that the composition of volatile concentrate from the human milk sample was very different from that of the cow milk sample. In the human milk aldehydic compounds had a first sensory importance and volatile fatty acids had a secondary importance. The sensory contribution of lactones was not made clear although they surely played a role in developing milky odor.

\section{REFERENCES}

Badings, H. T. 1991 Milk. In Volatile compounds in foods and beverages; Maarse, H., Ed.; Dekker: New York, pp 91-106.

Badings, H. T. 1984 Flavor and off-flavours. In Dairy Chemistry and Physics, Walstra, P. and Jenness, R. Ed.; Wiley, New York, pp 336-35.

Belitz, H. -D. and Grosch, W. 1987 Food Chemistry; translated by Hadziyev, D., Springer-Verlag: Berlin, pp $128-200$.

Buttery, R. G., Teranishi, R. and ling, L. C. 1987 Fresh tomato aroma volatiles: A quantitative study. J. Agric. Food Chem., 35, 540-544.

Buttery, R. G., Stern, D. J. and Ling. L. C. 1994 Studies on flavor volatiles of some sweet corn products. J. Agric. Food Chem., 42, 791-795.

Cha, Y. J. and Cadwallader, K. R. 1998 Aroma-active compounds in skipjack tuna sauce. J. Agric. Food Chem., 46, 1123-1128.

Christic, W. W. 1983 In Development of Dairy Chemistry Vol. 2; Fox, P. F. Ed.; Elsivier Applied Science Pub. London, pp 14.

Contarini, G.; Povolo, M; Leardi, R. and Toppino, P. M. 1997 Influence of heat treatment on the volatile compounds of milk. J. Agric. Food Chem., 45(8), 3171-3177.

Dartey, C. K. and Kinsella, J. E. 1971 Rate of formation of methyl ketones during blue cheese ripening. J. Agric. Food Chem., 19, 711-714.

Forss, D. A. 1979 Reviews of the progress of dairy science. Mechanisms of formation of milk and milk products. J. Dairy Res., 46, 691-706.

Gaafar, A. M. 1991 Chemical changes in ultra-high-treated milk during storage. 2. Production of 
volatile flavor compounds. Milch-wissenschaft, 46, 233-235.

Gallois, A. and Langlois, D. 1990 New results in the volatile odorous compounds of French blue cheese. Lait., 70, 89-106.

Hawke, J. C. 1966 Reviews of progress in dairy science. The formation and metabolism of methyl ketones and related compounds. J. Dairy Res., 33, 225-243.

Karahadian, C. and Johnson, K., A. 1993 Analysis of headspace volatiles and sensory characteristics of fresh corn Tortillas made from fresh Masa dough and spray-dried Masa flour. J. Agric. Food Chem., 41, 791-799.

Mennella, J. A. 1995 Mother's milk: a medium for early flavor experiences. J. Human Lactation, 11, $39-45$.

Moio, L.; Dekimpe, J.; Etievant, P. and Addeo, F. 1993a Neutral volatile compounds in the raw milks from different species. J. Dairy Res., 60, 199-213.

Moio, L.; Langlois, D.; Etievant, P. and Addeo, F. 1993b Powerful odorants in bovine, ovine, caprine and water buffalo milk determined by means of gas chromatography-olfactometry. $J$. Dairy Res., $\mathbf{6 0}$, 215-222.

Moio, L.; Etievant, P.; Langlois, D.; Dekimpe, J. and Addeo, F. 1994 Detection of powerful odorants in heated milk by use of extract dilution analysis. J. Dairy Res., 61, 385-394.

Milo, C. and Grosch, W. 1993 Changes in the odorants of boiled trout (Salmo fario) as affected by the storage of the raw material. J. Agric. Food Chem., 41, 2076-2081.

Palmquist, D. L.; Beaulieu, A. D. and Barbano, D. M. 1993 Feed and animal factors influencing milk fat composition. J. Dairy Sci., 76, 1753-1771.

Rerkrai, S.; Jeon, I. J. and Bassette, R. 1987 Effect of various direct ultra-high temperature heat treatment on flavor of commercially prepared milk. J. Dairy Sci., 70, 2046-2054.

Osawa, N. 1987 Dairy products and their flavors. Koryo, 153, 37-47.

O'Neill, T. E. and Kinsella, J. E. 1987 a Binding of alkanone flavors to $\beta$-lactoglobulin: Effects of conformational and chemical modification. J. Agric. Food Chem., 35, 770-774.

O'Neill, T. E. and Kinsella, J. E. $1987 \mathrm{~b}$ Flavor protein interactions: Characteristics of 2-nonanone binding to isolated soy protein fractions. J. Food Sci., 52, 98-101.

Shiratsuchi, H.; Shimoda, H.; Imayoshi, K.; Noda, K. and Osajima, Y. 1994a Volatile flavor compounds in spray-dried skim milk powder. J. Agric. Food Chem., 42, 984-988.

Shiratsuchi, H.; Shimoda, M.; Imayoshi, K.; Noda, K. and Osajima, Y. $1994 \mathrm{~b}$ Off-flavor compounds in spray-dried skim milk powder. J. Agric. Food Chem., 42, 1323-1327.

Shiratsuchi, H.; Yoshimura, Y.; Shimoda, M.; Noda, K. and Osajima, Y. 1995 Contributors to sweet and milky odor attributes of spray-dried skim milk powder. J. Agric. Food Chem., 43, 2453-2457.

Van den Dool, H. and Kratz, P. D. 1963 A generalization of the retention index system included linear temperature programmed gas-liquid chromatography. J. Chromatogr., 11, 463-471.

Volatile Compounds in Food 1992 Qualitative and Quantitative Data, Maarse, H. and Visscher, C. A. Ed., TNO Biotechnology and Chemistry Institute, The Netherlands.

Wiley/NBS Registry of Mass Spectral Data, 1989 Wiley-Interscience: New York. 